\title{
Kritisk læsning af Koranen i muslimsk optik
}

\author{
Af Dorthe Maria Kodal \\ Fra slutningen af det 19. århundrede har en række muslimske tænkere bragt Koranen i fokus som en tekst, \\ der er central for en gentænkning af islam. I nyere tid har aktiviteten $\mathrm{i}$ den modernistiske forskning gået $\mathrm{i}$ \\ retning af en historisk relativering af Koranen og traditionen. Man er bevidst om den humane faktor $\mathrm{i}$ \\ medieringen af det guddommelige budskab, men forskerne er forskellige i forhold til deres vægtning af \\ tekstens autoritet og etik.
}

\section{Koranens betydning for gentænkningen af islam}

Det er en udbredt opfattelse, at Koranen ikke læses kritisk af muslimer, men faktisk har en række muslimske intellektuelle bevæget sig væk fra den traditionelle opfattelse af Koranen. Deres korankritik er et opgør med fundamentet for fortolkningen, den traditionelle opfattelse af, at Koranen som Guds åbenbarede tale ikke er betinget af menneskelige faktorer. Ofte kaldes denne tilgang til Koranen modernistisk i modsætning til den traditionalistiske eller islamistiske tilgang (se fx Rippin 2001, 218-245). Disse generelle betegnelser for strømninger i den muslimske tænkning specificeres af professor Abdullah Saeed i relation til opfattelsen af Koranen. Han skelner mellem den tekstualistiske, den semi-tekstualistiske og den kontekstualistiske indfaldsvinkel, idet han betoner opfattelsen af Koranen som et kontinuum, der går fra den bogstavtro forståelse af teksten til en tagen højde for, at teksten er skrevet i en bestemt socialhistorisk kontekst og har behov for fortolkning for at kunne passe ind i en moderne sammenhæng (Saeed 2004, 3). ${ }^{1}$

I denne artikel beskæftiger jeg mig udelukkende med den modernistiske/kontekstuelle tilgang til Koranen. Denne tilgang repræsenterer en historisk relativisme, som kan åbne for tekstens fortolkningsmuligheder. For at kunne forstå denne udvikling er det nødvendigt at undersøge udviklingen af fortolkningen og forståelsen af Koranen i den muslimske tradition. 


\section{Koranfortolkning i islamisk tradition}

Koranfortolkning er blevet udøvet siden Koranens fremkomst. Fortolkningsvirksomheden bliver evident i den litteratur, der opstår i det 8. og 9. århundrede, ${ }^{2}$ både den biografiske om profetens liv (sîra) og den litteratur, der beskæftiger sig med Koranens betydning. Denne kaldes på arabisk tafsîr eller ta'wîl. Begge ord betyder udlægning eller forklaring og er synonyme (Gätje 1971: 51). Som tiden gik, kom ta’wîl dog til specifikt at dække den metaforiske, allegoriske koranudlægning, mens tafsîr begrebet blev benyttet om ortodoks koranudlægning (ibid.). Man bruger i vestlige lande ofte betegnelsen korankommentar om denne genre, der enten vers for vers (tafsîr musalsal) eller tematisk (tafsîr mawdî $\hat{\imath}$ ) behandler dele af eller hele koranteksten ved at forklare betydningen ved hjælp af specifikke metoder. ${ }^{3}$

Tafsîr som genre har i klassisk tid været en del af de videnskabelige discipliner, som beskæftigede sig med Koranen ('ulûm al-qur'ân). Af disse kom retstænkningen (fiqh) til at få stor betydning i forhold til, hvordan Koranen slutteligt kom til at blive opfattet, nemlig hovedsageligt som en lovtekst (Saeed 2006: 17). Koranen selv indeholder dog ikke mange klare juridiske bestemmelser, hvilket påpeges af traditionskritiske forskere. ${ }^{4}$ Retstænkningen udviklede sig fra at have været baseret på skøn og hensyn til lokale skikke til næsten udelukkende at basere sig på de religiøse grundtekster, Koranen og hadith. $^{5}$

\section{Hadîth som autoritet i fortolkningen af Koranen}

Koranens etiske og lovmæssige bestemmelser var spredt i teksten og ofte ikke konkretiserede. Overleveringer om Muhammeds og hans samtidiges fortolkning af Koranens bestemmelser fik derfor større og større vægt. Systematiseringen af sharî́a samt et stigende fokus på tekst gik hånd i hånd med udviklingen af genren hadîth. For at udskille de falske hadîth fra dem, som virkelig stammede fra profeten, udviklede man en kritisk metode, som bestod i en undersøgelse af tradentkædens (isnâd) forskellige led. Kunne den person, som overleverede fortællingen fra en tidligere autoritet vides med sikkerhed at have mødt denne? Var alle tradenterne i en isnâd moralsk uangribelige? Var indholdet i overleveringen (matn) i overensstemmelse med Koranens lære? Efterhånden 
som profettraditionerne kom til at spille en større rolle inden for jurisprudens, og efterhånden som hadîth-kritikken mente at have frasorteret de utroværdige hadîth og kanoniseret de ægte, fik de status af åbenbaringer på linje med Koranen. Forskellen i autoritet skulle ikke findes i substansen af åbenbaringen, men i formen (Brown 1996: 7,16). Både Koranens tekst og dens indhold opfattes som værende af guddommelig oprindelse, mens dette for hadîths vedkommende kun gælder for indholdet. Denne udvikling i retstænkningen foregik gradvist, men blev cementeret af den tredje lovskoles grundlægger al-Shâfi'î (d. 822). Fra omkring år 900 var dette fokus på teksten så cementeret, at fremtidige bestemmelser næsten udelukkende skulle basere sig på taqlîd, streng efterfølgelse af de ortodokse skolers afgørelser. Denne praksis skabte en nedgang i religiøs kreativitet, der bredte sig til korankommentarerne.

De eksegetiske hadîth, som forklarede eller kommenterede Koranens tekst, var kun en del af det samlede traditionskorpus, men alligevel fik dette post-shâfi'îtiske fokus på Koranen og hadîth som lovtekster så stor betydning, at en senere tafsîr-teoretiker som Ibn Taymiyya (d. 1328) mente, at Koranen skulle forklares ud fra sig selv eller ud fra hadîth, først og fremmest profetens udlægning, dernæst hans samtidiges udlægning, og hvis dette ikke kunne lade sig gøre, måtte man i nødstilfælde strække sig til en udlægning fra en af deres efterfølgere (al-tafsîr al-ma'thûr) (Rippin 2001: 156-157). Den voksende afhængighed af traditioner kom til at betyde, at udlægningen af Koranens etiske og lovmæssige stof efter denne metode begrænsede rækkevidden for fortolkning og nytænkning (Saeed 2006: 17).

\section{Det 20. århundredes koranforskere}

Stagnationen i den religiøse tænkning har undret mange og har fået skyld for at være årsag til den manglende økonomiske og sociale udvikling i de muslimske lande i moderne tid. ${ }^{6}$ Den generelle opfattelse har været, at fordi idjtihâds (evnen til selvstændigt at argumentere og træffe afgørelser) dør lukkedes, har der kun været få store islamiske reformister, og man har i sunni-islam fulgt den ortodokse lære, som udvikledes i den formative periode. Den meget elitære og konservative koraneksegese og påvirkningen fra det industrielt og teknologisk overlegne Europa skabte i slutningen af det 19. århundrede 
hos muslimske intellektuelle ønsket om en koranlæsning, der havde umiddelbar relevans for befolkningen. Denne genlæsning skulle integrere de nye udviklingsmuligheder, men var samtidig et led i en modstandsbevægelse og en selvbevidstgørelsesproces.

\section{Hadith-kritikere}

Den indiske jurist og forfatter Sayyid Ahmad Khan (1817-98) mente, at Koranens fortolkning burde befries helt fra den begrænsning, hadîth pålagde den. Hadîth-baseret udlægning binder Koranens mening til en bestemt historisk situation. Koranens mirakel er dens universelle og evige gyldighed, og ved en rationel udlægning kan man til enhver tid og enhver situation finde et svar deri. Ahl i-Qur'ân bevægelsen i Indien i det tidlige 20. århundrede, som pointerede Koranens autoritet som primær i forhold til hadîth, var stærkt inspireret af Ahmad Khans tanker. Også den ægyptiske lærde, Muhammed Abduh (1849-1905) anlagde et kritisk syn på hadîth, om end ikke helt så radikalt som Ahmad Khan. En række ægyptiske traditionskritikere gik endnu længere i deres kritik og skabte bl.a. sloganet islam er Koranen alene (Zayd 2004: 51). Både Ahmad Khan og Muhammed Abduh mente, at tekstens mening skulle kunne tilpasse sig den moderne verden, i særdeleshed den videnskabelige og teknologiske udvikling, og at teksten skulle udlægges i en form, så den kunne forstås af og vise sin relevans for lægfolk.

\section{Vestlig korankritiks betydning for gentænkningen af Koranen}

Den tidlige europæiske hadîth-kritik havde indflydelse på Sayyid Ahmad Khans afvisning af pålideligheden af hadîth og fik dermed indirekte betydning for Ahl i-Qur'ân bevægelsen (Zayd 2004: 50-51). Vestens historisk-kritiske interesse deles dog sjældent af muslimske forskere, og mange mener, at den historisk-kritiske metode afspejler en orientalistisk mentalitet, der forsøger at fratage den muslimske verden sin identitet (Se fx Manzoor 2001: 382, 384).

Den fransk-algierske filosof Muhammed Arkoun (f.1928), nu professor emeritus i idéhistorie ved Sorbonne i Paris, forsøger at sætte sig ud over splittelsen mellem den interne muslimske og den eksterne sekulære forskningstradition. Han ønsker alle humanog samfundsvidenskabelige discipliner som fx antropologi, filosofi og semiotik bragt til 
anvendelse i studiet af islam og Koranen, fordi ingen menneskelig viden kan sætte sig ud over sproget og historien. Arkoun mener ikke, at anvendelsen af den historisk-kritiske metode er løsningen på muslimers aktuelle behov (Rippin 2001: 243-244), og det viser sig da også, at de fleste moderne islamiske hermeneutikere arbejder inden for troens rammer, uden at det er en forhindring for nye fortolkningsmuligheder. Doktrinen om Koranen som Guds evige og uskabte tale er så central for troen, at kun få stiller spørgsmål til den. ${ }^{7}$ Visse forskere mener endda, at netop denne opfattelse åbner for nye forståelser, da kravet om tekstens relevans til alle tider netop kræver en genlæsning i tid og rum (Barazangi 2004: 5).

I nyere tid har koraneksegesen inden for den muslimske tradition bevæget sig i flere retninger. Der skrives fortsat inden for den traditionelle eksegetiske genre, ligesom de klassiske tafsîr-værker stadig bliver læst. I Ægypten har den litterære læsning af Koranen haft gode kår ved Cairos universitet. Flere af de værker, som omhandler Koranen, er dog ikke klassisk tafsîr, men hermeneutiske værker, der forsøger at gøre op med den traditionelle forståelses metode og teori. Hvor stor en betydning, de uortodokse værker i virkeligheden har, er et stående spørgsmål, men har ikke vundet bred anerkendelse hos teologer og retslærde (Wielandt 2002: 139-40).

En del tænkere arbejder med de etiske og retslige aspekter af Koranen. Opfattelsen af Koranen som religiøs lovtekst har været den fremherskende i muslimsk tradition så længe, at det bliver en diskussion om rammerne for troen. Denne tilgang er pragmatisk: Et opgør med en konservativ tekstfokuseret tradition er nødvendig. Hvorledes kan dette opgør foretages, uden at man træder uden for troens rammer? ${ }^{8}$. Gentænkningen af Koranens etiske karakter har dog ikke mere end 40 år på bagen (Saeed 2006: 14). Man kan indvende, at det er reduktionistisk at opfatte Koranen udelukkende som en etiskmoralsk forskrift for muslimers liv (Körner 2005: 196), og det er spørgsmålet, om denne side overvurderes af forskere i den vestlige tradition, ${ }^{9}$ men det er tydeligvis denne tilgang til Koranen, der har flest eksponenter i nyere tid. 
I det følgende præsenteres to retninger, der er repræsentative for den nyeste forskning: dels den, som lægger vægt på relevansen af en etisk gentænkning, dels den, som kan karakteriseres som sprogteoretisk. De karakteriseres begge ved deres forhold til teksten, der anskues som guddommeligt åbenbaret.

\section{Den tekstbundne nytænkning}

\section{Fazlur Rahman}

Fazlur Rahman (1919-1988) blev i 1960 udnævnt til direktør for Pakistans Central Institute for Islamic Research af landets daværende leder, general Ayyûb Khan. Fazlur Rahman, som var uddannet på Oxford University, samlede omkring sig en gruppe af universitetsuddannede forskere inden for sekulære discipliner som økonomi, sociologi, statskundskab etc. Formålet med instituttet var, at det skulle tjene som et rådgivende organ for nationalforsamlingen. Da Pakistans familielovgivning blev vedtaget i 1962, blev der rettet kritik mod instituttet, fordi Koranen og sunna blev tolket meget liberalt, bl.a. blev loven om polygami kraftigt indskrænket. Rahmans bog Islam, a General Introduction (årstal) skabte uro i befolkningen og førte til demonstrationer mod ham personligt, mod instituttet og mod landets ledelse. De religiøse lærde beskyldte Rahman for kætteri, Ayyûb Khan måtte træde tilbage, og Fazlur Rahman blev tvunget til at forlade landet i 1969, hvorefter han indtil sin død fungerede som professor ved University of Chicago (Zayd 2004: 52-53).

Fazlur Rahman repræsenterede en hadîth-skeptisk tilgang, som dels blev udviklet i Indien, dels i Ægypten i det 19. og tidlige 20. århundrede. Han var arvtager til hadîthkritiske forskere som Sayyid Ahmad Khan og Ghulam Ahmad Parwez (1903-1985). Begge valgte på baggrund af autenticitetsproblemet at afvise hadith som autoritet (for Parwez, se Brown 1999: 48). Fazlur Rahman valgte dog ikke helt at frasige autoriteten af profetens sunna, men adskilte begrebet fra hadith-litteraturen, hvis autenticitet var omstridt. Her åbnede han for en historisk-kritisk forskning i kilderne. Han plæderede for en såkaldt holistisk læsning af Koranen som modsætning til den atomistiske læsning, der ofte benyttedes af tekstualisterne. Han mente, at det var vigtigt at udvikle generelle principper på baggrund af koranteksten som helhed. Men samtidig var det vigtigt, at disse 
principper blev appliceret i forhold til det konkrete samfund. Han udviklede hertil en hermeneutisk metode, han kaldte "double movement theory" (Rahman 1982: 5). Læseren skulle bevæge sig tilbage til Koranen og af dens tidsspecifikke påbud udvikle generelt gældende etiske principper. Dernæst kunne man bevæge sig frem til nutiden og benytte disse generelle principper som basis for dannelse af nye love og forordninger $\mathrm{i}$ overensstemmelse med nutidens betingelser (Rahman 1982: 13-22).

Fazlur Rahmân repræsenterer et opgør med traditionen, men ikke et radikalt brud. Hans tanker er blevet fulgt af mange muslimer, der har følt behovet for en gentænkning af det etiske aspekt af Koranen, fx de feministiske forfattere Amîna Wadûd-Muhsin (WadûdMuhsin 1993) og Nimat Hafez Barazangi (Barazangi 2004).

\section{Abdullah Saeed}

Abdullah Saeed, professor og leder af Centre for the Study of Contemporary Islam ved University of Melbourne, lægger sig i sin opfattelse af tekst og tradition tæt op ad Fazlur Rahman, hvis metodiske overvejelser han komplementerer ved at give et konkret bud på, hvordan man kan udlede generelle værdinormer (i Rahmans terminologi: generelle principper). Disse værdinormer udleder Saeed dels af Koranens bestemmelser, dels ved at bygge på de første muslimers eksempel og senere teologers udarbejdning af generelle værdisæt i den såkaldte maqâsid-litteratur (Saeed 2006: 126-129). ${ }^{10}$ Han inddrager på selektiv måde traditionen i sin gentænkning, men forholder sig historisk-kritisk til den. Koranens betydning skabes nemlig ifølge Saeed ikke som et resultat af afsenderens intention alene, men af en interaktiv proces mellem afsender og modtager, hvori læseren deltager aktivt (Saeed 2006: 149). Hans anliggende er specifikt de etisk-juridiske vers i Koranen, et område, som han mener, indtil 1960'erne er blevet forsømt i Koranfortolkningen, såvel den modernistiske som den traditionelle. Rationel tænkning har ganske vist bevæget sig ind i det 20. århundredes koranfortolkning i den forstand, at mytiske og irrationelle træk i Koranen ikke længere forstås bogstaveligt, fordi det hævdes, at Koranens indhold ikke kan stå i modsætning til den moderne naturvidenskabs opdagelser. Dette har dog ikke indebåret en metodisk gentænkning af de etisk-juridiske bestemmelser i Koranen (Saeed 2006: 14). 
Fazlur Rahman har udover Saeed ligeledes inspireret tænkere fra Tyrkiet, der som Saeed inddrager historisk-kritisk metode i deres etiske gentænkning af Koranen (Körner 2005: 203). Universitetsteologer som Mehmet Paçaci, Adil Çiftçi, Ömer Özsoy og Ilhami Güler arbejder alle med Rahmans hermeneutik i deres forsøg på at skabe en moderne etik, baseret på Koranen og de tidligste muslimers eksempel. Selvom Tyrkiets historie adskiller sig væsentligt fra resten af den islamiske verden, dels ved ikke at have været koloniseret, dels ved Atatürks indførelse af et sekulært uddannelsessystem, er Tyrkiet måske det eneste muslimske land, som i statsligt regi arbejder revisionistisk.

\section{At gå ud over teksten}

Nasr Abû Zayd

Nasr Abû Zayd, tidligere lektor ved Cairo University, blev i 1995 erklæret frafalden af en ægyptisk domstol og tvangsskilt fra sin kone, fordi han havde omtalt Koranen som et kulturelt produkt. Af sikkerhedsårsager måtte han og hans kone forlade Ægypten, og han er nu professor ved Universiteit voor Humanistiek i Utrecht. Zayd er i sin litterære tilgang til Koranen fulgt i sporene af sine forgængere Amîn al-Khûlî (d. 1967) og Muhammed Khalaf Allâh (1916-1998). I sin bog Mafhûm al-Nass (Forståelsen af Teksten) fra 1990 fremlægger Zayd sine betragtninger om Koranen som en tekst, der skal analyseres som en sådan. En tekst skal betragtes som kodet information i den forstand, at indholdet overføres ved et tegnsystem, der er modtageren bekendt. Derfor skal en helligtekst, der opfattes som en meddelelse fra Gud, kodes i et sprog, som modtageren, i dette tilfælde Muhammed og hans samtidige, kunne forstå. ${ }^{11}$

I Holland udgav Zayd i 2004 bogen Rethinking the Qur'ân: Towards a Humanistic Hermeneutics, hvori han anerkender Mohammed Arkouns opdeling af Koranen i diskurs og fikseret tekst. Arkoun skelner i sin koranlæsning mellem de oprindelige profetudsagn og det endelige kanoniserede tekstkorpus, som han kalder "Closed Official Corpus" (Arkoun 1994: 35). Han beklager den lukkethed, der blev resultatet af kanoniseringen. I sin opfattelse af åbenbaringens afhængighed af en specifik sproglig og historisk kontekst adskiller han sig ikke fra Rahman og Saeed, ligesom Muhammed Arkoun også via en 
tværdisciplinær tilgang til Koranen mener at kunne udlede det oprindelige koranske budskab. Nasr Abû Zayd mener i Muhammed Arkouns opdeling at have fundet en metode til at frigøre den oprindelige koran fra de fastfrostne betydninger, den har fået i traditionen. Hele Koranen er en dialog mellem Gud og de vantro, Gud og de kristne, Gud og jøderne, alt sammen med Muhammed som medium. Zayd spørger så: Hvad er Koranens egentlige budskab i denne dialog, et budskab om sameksistens eller et budskab om isolation? Han svarer selv, at da dialogaspektet er en del af Koranens struktur, må han betragte det som en invitation til muslimer til at gentænke Koranen (Zayd 2004: 63).

Hvori ligger så forskellen mellem Arkouns og Zayds tænkning på den ene side og Rahmans og Saeeds på den anden? Da alle parter er meget traditionskritiske, men alligevel anerkender den muslimske baggrundshistorie som et historisk faktum eller i det mindste som en arbejdshypotese, er det i omgangen med koranteksten, at de adskiller sig væsentligt fra hinanden. Koranens mening må ifølge Arkoun og Zayd løses fra den stivnede form, den har fået i ortodoksien. Zayd mener, at Koranen i sin diskursive struktur lægger op til dialog og forhandling, mens Arkoun stiller spørgsmål ved, om tekstens form og indhold svarer til det oprindelige guddommelige budskab. Rahman og Saeed går ikke så vidt. Selve Koranens struktur rører de ikke ved, og de fastholder relevansen af udviklingen af et nyt generelt regelsæt og en ny lovgivning på baggrund af en metodisk gentænkning af Koranens overordnede budskab.

\section{Gentænkning af Islam: Et elitært europæisk fænomen?}

De ovenfor behandlede forfattere repræsenterer alle en modernistisk, kontekstuel tilgang til Koranen. De arbejder alle inden for en konfessionel, teologisk ramme, men anerkender Koranens placering $\mathrm{i}$ en historisk kontekst, og at den derfor skal fortolkes for at få budskabet frem. Fokus og den metodiske tilgang er forskellig. Rahman og Saeed m.fl. mener, at de muslimske kilder med held kan studeres historisk-kritisk for at kunne uddrage en etik, som kan være muslimers rettesnor i en moderne verden. Arkoun mener, at dette ikke er muligt, da der ikke findes en menneskelig viden, som er uafhængig af sproget og historien (Rippin 2001: 242-243). 
Deres tilgang til tekstens autoritet er forskellig. Fazlur Rahman opstillede en model for en gentænkning af de etiske aspekter i Koranen. Han arbejdede ud fra den kanoniserede tekst, og i sin model for en kontemporær gentænkning af dens normative aspekter ser han det som ønskeligt at inddrage profetens sunna. Denne skal dog stemme overens med Koranens hele budskab og uddrages gennem en kritisk analyse af de omstændigheder, hvori Koranens bestemmelser blev åbenbaret (Rahman 1982: 143). Saeed viderefører dette arbejde ved konkret at give eksempler på, hvilke værdisæt der kunne udledes af Koranen og ved at arbejde historisk-kritisk med teksterne, men inden for en forståelse af den kanoniserede koran som etisk rettesnor for muslimer. Arkoun og Zayd derimod bevæger sig ud over teksten og autoritetsbegrebet ved at betragte Koranen som en diskurs og en dialog, der ikke begrænser sig til den kanoniserede tekst. På denne måde åbnes for en nytænkning af det transcendente, som ikke alene er bundet til tekstens autoritet.

Tanker som Mohammed Arkouns og Nasr Abû Zayds har dog ikke vundet anerkendelse i muslimske kredse. Konfessionelle studier af Koranen efter Rahmans metode har flere tilhængere, og det kan tyde på, at en modernistisk gentænkning af traditionen på trods af Arkouns skepsis foregår under disse forudsætninger. Robert D. Lee skriver i indledningen til sin oversættelse af Mohammed Arkouns bog Rethinking Islam, at gentænkning af islam forudsætter et liberalt styre og derfor indtil videre må foregå i Vesten (Arkoun 1994: xi). Spørgsmålet er, hvor stor indflydelse denne gentænkning vil kunne få i den muslimske verden, og om den overhovedet vil blive anerkendt blandt muslimer i Europa. En anden hindring i denne henseende er, at udgivelserne ofte er tiltænkt et internationalt publikum og derfor er på sprog som fransk og engelsk, hvilket også begrænser deres udbredelse (Saeed 2006: 147). Vil en nytænkning i Europa og andre steder gå i front for en transformationsproces, der sluttelig vil lægge pres på den muslimske verden, dens ortodokse religiøse institutioner og politiske magthavere? ${ }^{12}$ I alle tilfælde må vi sande, at nytænkningen i det sidste århundrede i Ægypten og Pakistan har stagneret jf. behandlingen af Rahman og Zayd. De nye strømninger kommer fra Europa, USA, Sydøstasien og Sydafrika. Desuden er Tyrkiet et spændende land at følge i forhold til udviklingen af en islamisk teologi, der medtænker den historisk-kritiske metode. Selvom landet aldrig har været koloniseret og på mange måder føler sig tættere knyttet til 
Europa end mange andre muslimske lande, kan udviklingen alligevel fortælle os meget om, hvordan en transformationsproces kan foregå i en brydning mellem tradition og modernitet.

\footnotetext{
${ }^{1}$ Begreberne modernisme/islamisme på den ene side og semi-tekstualisme/kontekstualisme på den anden overlapper hinanden på så afgørende punkter, at der er behov for yderligere specificering af forskellen mellem de to moderne udviklinger af islamisk tænkning.

${ }^{2}$ Selvom vi først besidder kildemateriale fra omkring år 800, udelukker det ikke en tidligere skriftlig tradition. Muligvis har disse tidligere tekster blot ikke overlevet (Berg 1997: 16).

${ }^{3}$ Se fx Berg (2000: 148-157).

${ }^{4}$ Ifølge Zayd (2004: 36) har 500 vers i Koranen, altså 16 \% lovmæssig betydning. Ifølge Saeed (2006: 20) drejer det sig om mellem 80-100 tilfælde. Han baserer dette på Coulson (1964: 12).

${ }^{5}$ De profetiske traditioner, nedfældet i de seks autoritative samlinger, fortrinsvis Bukhârîs (død 870) og Muslims (død 875).

${ }^{6}$ Som en kuriøsitet kan nævnes den nationistiske antagelse hos den tyrkiske teolog Ilhami Güler, at denne tilbageståenhed er en del af arabernes mentalitet, deres konservatisme og infleksibilitet. Denne vurdering muliggør for ham en særlig, og overlegen, tyrkisk fortolkning af Koranen (Körner 2006: 200).

${ }^{7}$ Güler mener, at doktrinen om Koranens uskabthed er medansvarlig for stagnationen inden for islamisk tænkning (Körner 2005: 172).

${ }^{8}$ Felix Körner formulerer det således: "The revisionists' vision is still restricted to one type of questions: ethics....... Hermeneutics has then a merely mechanical function: we know what is there in the Koran, ethics, and we know what must come out, modern ethics. The only question left is, how do we get it out? Hermeneutics has become a tin-opener." (Körner 2005: 204)

${ }^{9}$ Den rytmiske og rimede recitation (tadjwîd) er et æstetisk og emotionelt aspekt af Koranen, hvis betydning hidtil er veget for en mere tekstbaseret forståelse. Nasr Abû Zayd mener endda, at betydningen af Koranen først rigtigt kommer frem i recitationen. Ifølge Zayd er det æstetiske og sanselige indtryk et behov hos den troende, og når han hører Koranen blive reciteret, hører han Gud selv tale. Gud bliver nærværende, og den troende bliver nærværende over for sig selv i dette ritual (Abû Zayd 2001: 19).

${ }^{10}$ maqâsid al-sharî́a: Målsætningerne for sharî'a. De vigtigste repræsentanter for denne litteratur er alGhazâlî (d. 1111) og al-Shâtibî (d. 1388).

${ }^{11}$ I sin forståelse af kommunikation er han inspireret af den russisk-amerikanske linguist Roman Jakobson, hvis teori går tilbage til den amerikanske matematiker og informationsteoretiker Claude E. Shannon (Wielandt 1996: 260).

${ }_{12}$ Magthaverne og den ortodokse religiøse elite i de muslimske lande legitimerer ofte gensidigt hinanden og får den brede befolknings opbakning ved at appellere til den sammenhængskraft, der ligger i en fælles islamisk ideologi. Dette gør det let at afvise nye eksegetiske initiativer. Herudover benyttes ligheden mellem den liberale eksegeses metoder og konklusioner og vestlig videnskab som argument mod en accept af disse metoder og slutninger (Wielandt 2002: 140).
}

\section{References}

Abû Zayd, Nasr, 2001: Ein Leben mit dem Islam, Herder, Freiburg/Basel/Wien. , 2004: Rethinking the Qur'ân: Towards a Humanistic Hermeneutics, SWP Publishers, Amsterdam.

Arkoun, Mohammed, 1988: "The Notion of Revelation: From Ahl al-Kitab to the Societies of the Book", in: Die Welt des Islams, New Series, vol. 28, 62-89. 
, 1994: Rethinking Islam. Common Questions, Uncommon Answers, Westview Press, Boulder

Barazangi, Nimat Hafez, 2004: Woman's Identity and the Qur'an, University Press of Florida, Florida.

Berg, Herbert, 2000: The Development of Exegesis in Early Islam, Curzon, Richmond, Surrey.

_ 1997: "The Methods and Theories of John Wansbrough", in: Willi Braun, Darlene Juschka, Arthur McCalla, Russell McCutcheon (eds.): Method and Theory in the Study of Religion, vol. 9-1, 3-22.

Brown, Daniel W., 1999: Rethinking Tradition in Modern Islamic Thought, Cambridge University Press, Cambridge

Coulson, Noel. J., 1964: A History of Islamic Law, University Press, Edinburgh.

Gätje, Helmut, 1971: Koran und Koranexegese, Artemis, Zürich/Stuttgart.

Jeffery, Arthur, 1937: Materials for the History of the Text of the Qur'an, E.J. Brill, Leiden.

Körner, Felix, 2005: Revisionist Koran Hermeneutics in Contemporary Turkish University Theology, Ergon Verlag, Würzburg.

Luxenberg, Christoph, 2000: Die Syro-aramäische Lesart des Koran, Das Arabische Buch, Berlin.

Manzoor, S. Parvez, 2001: "Method Against Truth: Orientalism and Qur'ânic Studies", in: Andrew Rippin (ed.): The Qur'ân: Style and Contents, Ashgate, Aldershot/Brookfield USA.

Puin, Gerd R., 1996: “Observations on Early Qur'an Manuscripts in San'â'”, in: Stefan Wild (ed.): The Qur'an as Text, E.J. Brill, Leiden.

Rahman, Fazlur, 1982: Islam and Modernity. Transformation of an Intellectual Tradition, The University of Chicago Press, Chicago.

Rippin, Andrew, 2001: Muslims. Their Religious Beliefs and Practices, Routledge, London.

Saeed, Abdullah, 2006: Interpreting the Qur'ân. Towards a Contemporary Approach, Routledge, London. 
Wadud-Muhsin, Amina, 1993, Qur'an and Woman, Penerbit Fajar Bakti, Kuala Lumpur.

Watt, William M. \& Richard Bell, 1991: Bell's Introduction to the Qur'an, Edinburgh University Press, Edinburgh.

Wansbrough, John, 1977: Qur'ânic Studies: Sources and Methods of Scriptural Interpretation, Oxford University Press, Oxford.

Wielandt, Rotraud, 1996: "Wurzeln der Schwierigkeit innerislamischen Gesprächs über neue hermeneutische Zugänge zum Korantext”, in: Stefan Wild (ed.): The Qur'an as Text, E. J. Brill, Leiden.

2002: “Exegesis of the Qur'ân: Early, Modern and Contemporary”, in: Jane Dammen McAuliffe (ed.): Encyclopaedia of the Qur'an, Brill, Leiden.

Dorthe Maria Kodal er cand.mag. i arabisk sprog og islamisk kultur samt hebraisk sprog og kultur og ph.d.stipendiat ved Afdeling for religionsvidenskab, Aarhus Universitet. 